\title{
Is organic agriculture a viable strategy in contexts of rapid agrarian transition? Evidence from Cambodia
}

\author{
Alice Beban \\ Cornell University
}

Submitted July 1, 2013 / Revised August 21, 2013, and November 15, 2013 / Accepted November 18, 2013 /

Published online February 24, 2014

Citation: Beban, A. (2014). Is organic agriculture a viable strategy in contexts of rapid agrarian transition? Evidence from

Cambodia. Journal of Agriculture, Food Systems, and Community Development, 4(2), 131-147.

http://dx.doi.org/10.5304/jafscd.2014.042.004

Copyright (C) 2014 by New Leaf Associates, Inc.

\begin{abstract}
This paper draws on evidence from a field study of three organic agriculture development projects in Cambodia to look critically at the pursuit of organic agriculture as a rural development strategy in a context of rapid agrarian transition. I find that organic agriculture is a successful strategy for some households to improve the viability of land-based livelihoods as part of broader livelihood strategies, particularly within projects most closely aligned with an agroecological understanding valuing diversity and farmer knowledge. However, there are inherent contradictions in prescribing northern, market driven notions of farming success into the very different cultural and ecological settings of the Global South, and certification requirements, resource constraints and labor requirements can exclude some farmers. I argue that analysis of organic-farming as a rural development strategy needs to understand not just the direct economic
\end{abstract}

Alice Beban, Cornell University, Department of Development Sociology, Ithaca, New York 14853 USA. Mailing address: 707 Hasbrouck Apartments, Ithaca, New York 14850 USA; +1-607-793-0023; abb95@.cornell.edu returns, for the non-economic aspects, the broader socio-political contexts of uneven agrarian transition, and the ideology and practices of development agencies have a large bearing on the poverty reduction potential of organic farming.

\section{Keywords} agrarian transition, Cambodia, Global South, international development, livelihoods, organic agriculture

\section{Introduction}

Cambodia, like many countries in the Global South, is undergoing a rapid agrarian transition as processes of rural and urban change make farmingbased livelihoods less viable and off-farm options more accessible. A resurgent literature on processes of agrarian transformation in Southeast Asia seeks to understand these changes, drawing on classic questions on the fate of the peasantry in capitalism (Kautsky, 1899; Lenin, 1956) while recognizing the complexity of livelihood diversification, state and civil society roles, and new international and urban interests in land (for a review see Akram-Lodhi and Kay, 2010a and 2010b). Rural land-based liveli- 
hoods in Southeast Asia are increasingly perceived as more risky than urban migration and wage work, and wealth may not map so neatly onto land ownership as in the past (Rigg, 2006; 2012). In this uncertain context, a key question in rural development is whether pathways out of agriculture may therefore constitute the best form of poverty reduction for the rural poor (Li, 2009; Rigg, 2006; Thavat, 2011; World Bank, Public Information Center, 2006).

In this paper I provide one perspective on this question by considering the promotion of organic agriculture as a development strategy for smallholders in Cambodia. This inquiry is inspired by a growing collection of research — including pleas in the popular press for shoppers to "stop obsessing about your arugula... [It] is no recipe for saving the world's millions" (Paarlberg, 2010, para. 1) — that raises the question of whether organic agriculture may entrench poverty rather than increasing wellbeing if it requires more labor with uncertain income benefits (Barham \& Callenes, 2011; Paarlberg, 2010; Taotawin, 2010; Thavat, 2011). This argument suggests that rural people may be better off selling their land and moving to urban areas for wage work, or pursuing modern laborsaving agriculture and freeing up labor for wage labor and other rural nonfarm employment opportunities (Rigg, 2006; Thavat, 2011). I seek to deepen this debate, using research on three organic agriculture development projects in Cambodia to make two related arguments: First, the broader, usually implicit, frame of this debate is the larger structural context of agrarian transition, and explicit research attention needs to move beyond the economics of the farm unit to the uneven, contingent agrarian transitions in which farmers make constrained choices involving multiple ruralurban livelihoods. Second, there is a need to move away from concepts of "organic" as morally superior or overtly negative, to appreciate the heterogeneity of organic agriculture development initiatives and the diversity of outcomes for different groups. Organic agriculture in Cambodia, as in much of the Global South, is promoted primarily as a rural development strategy for poverty reduction through nongovernmental organizations (NGOs) and donor agencies. The range of organic initiatives in Cambodia reflects the ideologies of the development agencies and their understandings of how the agrarian question in Cambodia is best resolved, and these initiatives shape (and are shaped by) farmers' access to resources and ability to benefit from organic farming. Overall, my analysis shows that participation in organic farming development projects is a successful strategy for some households, but it is not a panacea for rural poverty in Cambodia. Direct economic benefits are uncertain; non-economic benefits, broader contexts of uneven agrarian transition, and development agency approaches have a large bearing on the poverty reduction potential of organics. I structure this paper in two broad sections: I outline the literature on organic agriculture in the Global South and explain Cambodia's agrarian transition; I then use my empirical research to draw out four themes that can broaden the debate on the potential for organics in the Global South.

\section{Organic Agriculture: Poverty Alleviation or Poverty Trap?}

Organic agriculture development projects in the Global South have proliferated since the late 1990s, and a growing body of research globally supports the notion that organic agriculture can enhance smallholder households' food security, whether or not they sell any of their harvest (Araya \& Edwards, 2004; Badgley et al., 2007; Parrott, Olesen, \& Høgh-Jensen, 2006). Farmers' incomes may increase through premium prices (Scialabba \& Hattam, 2002) and/or increased productivity (International Assessment of Agricultural Knowledge, Science and Technology for Development [IAASTD], 2008; Pretty et al., 2006), and organics may improve producer health, "cool" the planet, produce food more efficiently than large farms, and diversify growing systems (IAASTD, 2008). Although critical research on alternative food networks in the Global South has focused largely on fair trade (Bacon, 2005) and most critical theorizing of organics is developed from North American and European experiences (Allen \& Kovach, 2000; Guthman, 2004), an expanding research agenda examines smallholder organic agriculture in the Global South. Research in Latin 
America shows that expectations of organic price premiums benefiting farmers may be problematic, as price premiums from organic and fair trade certification are small, and migration remittances and yield increases (for farmers in programs with a technical training component) may have a greater effect on household income (Barham \& Callenes, 2011; Ruben \& Fort, 2012). Beuchelt and Zeller's (2011) survey of organic, fair trade, and conventional coffee producers in Nicaragua found that premium farm-gate prices for organic coffee did not translate into higher profit, due to increased labor costs. Organic producers were poorer relative to conventional producers throughout the 10-year study period. The organic producers had smaller farm sizes and larger family sizes, and the authors suggest that the higher labor requirements may limit the impacts on poverty alleviation. A central tension in certified organic farming is the simultaneous delinking from market-based chemical inputs in favor of knowledge-intensive techniques, and the deeper integration into distant markets, which may increase farmer vulnerability to global price fluctuations. This long-term perspective illuminates the possibility of "premium squeeze" as the entry of new farmers into an expanding organics market can lower farm-gate prices for producers, similar to the processes of "conventionalization" identified in North American and European organic sectors (Guthman, 2004). In Cambodia, Thavat (2011) finds that for "de facto" organic farmers (i.e., "traditional" farmers who do not use agricultural chemicals and gain organic certification on the basis of their existing farming system), labor requirements increased while price premiums were minimal, and the increased labor requirements could potentially keep households from accessing off-farm opportunities. Thavat concludes that organic agriculture development projects amongst de facto farmers "seems an absurd way to go about promoting "development" - paying paltry premiums to marginally increase the viability of precarious livelihoods" (p. 296). I build on Thavat's (2011) work in Cambodia by looking not only at de facto organic farmers but rather at a diversity of approaches and farming systems, which shows that organics can both promote and impede poverty reduction. Thavat
(2011) and other studies successfully draw attention to economic processes beyond farm-gate price premiums, including possible increases in labor requirements (including intensification of gendered unpaid family labor), and the recognition of opportunity costs whereby going organic may limit household ability to devote labor to migration or other income-earning opportunities. Barham and Callenes (2011) also look beyond the farm gate in their study of the importance of organic coffee production in the broader livelihood activities of Nicaraguan smallholders, and find that while organic production has increased, this is a much smaller percentage of household income than migration remittances from the United States. This underlines the importance of understanding the household farm as just one aspect of rural people's daily life, a perspective well articulated in the sustainable livelihoods approach that recognizes rural people's diverse occupations, and the increased fluidity of rural/urban livelihoods (Scoones, 2009).

Attention to rural livelihoods in agrarian transition needs to be combined with critical development theory, which recognizes the central role of the development organization in promoting organics. Organic agriculture has been promoted and financed in Global South contexts such as Cambodia through development agencies and NGOs as a development intervention, in contrast to its spread in the Global North largely through farmer-to-farmer adoption with market incentives and some government support (Vandergeest, 2011). Organic sectors in the Global South are still part of the broader global food system, and geared largely toward supplying food for niche-market consumers in the Global North and Southern urban elites, but historical contexts of colonialism and ongoing inequality in trade and global power relations are central to the experience in the South (Friedberg \& Goldstein, 2011). Gaps between farmer needs and desires and the mandates of development agencies, as well as divergent understandings of the value of farming as a livelihood, can shape the experiences of farmers in organic projects (Friedberg \& Goldstein, 2011;Li, 2007). The development sector is particularly influential in Cambodia, as the donor agencies and NGOs that proliferated in the post- 
conflict period have moved into many areas of rural development, and donor agency and NGO attitudes toward agrarian transition - what are the problems and changes in rural Cambodia, and what does a viable agriculture sector and broader rural livelihoods look like? - shape the projects they design. In Cambodia, these projects range from interventions which focus on farmers' limited global market opportunities, and therefore promote export-focused organic rice as a niche product for the European and American markets, to interventions which focus on ill health and debt as barriers to well-being, and therefore promote reduced chemical use and training in alternative methods of soil enrichment to reduce input dependence. Given that agrarian transformations and the ways these are understood by development agencies and farmers have a large impact on farmer experiences of organic agriculture, I now sketch out the national and global shifts that are transforming rural life in Cambodia.

\section{Background: Changing Rural Livelihoods in Cambodia}

A quarter century ago, Terence Byres (1986) argued that even the "classic" cases of agrarian transition to capitalism in Europe were diverse, and the resurgent literature on processes of agrarian transition in Southeast Asia shows that agrarian transformations are not natural, linear, or inevitable; rather, they are compelled by specific, complex forces (Hall, Hirsch, Li, 2011; Hart, Turton, \& White, 1989; Rigg, 2012). I do not use the term "transition" here to imply a tautology of movement through prescribed stages from an imagined starting point of a homogenous farming community (Bernstein, 1996), for rural Cambodians have long survived through multiple livelihood strategies, and plantation agriculture has roots in colonial rubber plantations. Shifting state policies alternately promoting smallholder land dispossession and periods of land reform mean movements away from the land and movements back to peasant agriculture both occur. However, the development of factor markets for land, capital and labor in the postwar period of neoliberal restructuring, the state support for large-scale agribusiness, and rapid increases in population, landlessness, and labor migration (table 1) signal a radically new landscape for rural Cambodians to negotiate.

Some key features of Cambodia's current agrarian transformation reflected in table 1 include:

- Demographic pressure and fragmentation of farms, with rapid population increase contributing to shrinking land holdings, particularly in populous areas around the Tonle Sap lake and coastal zones;

- Urbanization such that the proportion of people working in agriculture and agriculture's share of GDP has significantly decreased, even as the total population in agriculture has increased due to population growth;

- Land grabbing and concentration of land ownership, including the expansion of

Table 1. Cambodia Total Population, Agricultural Population, Landlessness, and Remittances

\begin{tabular}{|c|c|c|}
\hline & 1980 (unless stated) & 2005 (unless stated) \\
\hline Total population (millions) a & 6.8 & 13.9 \\
\hline Agricultural population (millions) a & 5.1 & 9.4 \\
\hline Agricultural population (\% total population) a & 76 & 68 \\
\hline Agriculture (\% GDP) b & $47(1993)$ & 33 \\
\hline Land granted to agribusiness concessions $(\mathrm{Ha})^{c}$ & $2,400(1995)$ & $2,106,345(2013)$ \\
\hline Landlessness (\% total population) d & $14(1997)$ & 28 (2009) \\
\hline $\begin{array}{l}\text { International migration remittances to Cambodia (USD } \\
\text { million) e }\end{array}$ & $12(1996)$ & $325(2008)$ \\
\hline
\end{tabular}

Notes: a Food and Agriculture Organization of the United Nations Statistics [FAOSTAT] (2013); b World Bank (2013); c Cambodian League for the Promotion and Defense of Human Rights [LICADHO] (n.d.); ; National Institute of Statistics [NIS] (1997; 2010a); e Kimsun (2011) 
large-scale agribusiness leases called "economic land concessions" (ELCs) for corporate agriculture and ongoing marketbased land accumulation, which contributes to increased concentration of land holdings and growing landlessness (Löhr, 2011; National Institute of Statistics [NIS], 2010b). Land concessions that benefit rural areas by increasing wage labor opportunities, even if they simultaneously limit land access for smallholders, although many of the concessions are used for speculation purposes and current research suggests employment is limited (Üllenberg, 2009);

- Legacies of conflict, including colonialism, civil war, forced collectivization, genocide, and the violence that continued until the late 1990s (Chandler, 2008; Heder, 1995), which leave their mark in widespread rural poverty, low use of both chemical fertilizers and traditional soil-enhancing techniques, and environmental degradation, due to resource accumulation by powerful military and political elite;

- A neoliberal capitalist agenda that since the 1990s has been promoted by international aid agencies and the ruling elite (Springer, 2009a; 2009b) and contributes to urbanfocused growth, rising land markets, and inequality (Üllenberg, 2009);

- Migrant remittances as an increasingly important income source; this may be invested in agriculture, but households in areas with established migration routes may prioritize migration and lack household labor for farming;

- The feminization and aging of the farm population is increasing as more young people migrate, and women-headed and elderly households become more common; and

- Farming's perception as "risky," due in large part to severe flooding and droughts that farmers perceive to be worsening, as well as commodity and land price fluctuations and exploitation by powerful interests.
The spatial diversity and social unevenness of these processes of transition has implications for the viability of organic farming as a poverty reduction strategy. Farmers in areas accessible to urban labor markets may experience labor shortages and limited access to land, and farmers in areas with economic land concessions may be reluctant to take up organics if they feel their tenure is insecure, and development agencies and NGOs may avoid contested areas (and indeed, largely fail to address the broader political "land question") given the potential for them to lose the favor of the ruling party if they are too vocal over politically sensitive issues.

\section{Research Methodology}

This research is based on qualitative semistructured research with members of organic farming development initiatives in Cambodia run by three different organizations: the German Organization for Technical Cooperation (GTZ) in Kampong Thom Province; the Community Cooperative for Rural Development (CCRD) in Pursat Province; and the Cambodian Center for Study and Development in Agriculture (CEDAC) NGO in Takeo and Prey Veng provinces. I held semistructured interviews of between one and four hours with 57 farmers, ran seven farmer focus groups, and held interviews with development agency staff and local government extension personnel. I held interviews in farmers' homes and asked about people's experiences in the organic programs and their broader livelihood activities. In most cases I concluded interviews with a walk around participants' rice fields. During focus groups, I adapted Mayers and Vermeulen's (2005) model of power mapping, whereby farmers constructed spider diagrams of ranked issues and actors that impacted their organics group, to understand the challenges farmers faced. I used these qualitative methods in order to understand farmers' own perceptions of their experiences with organic farming and how these meshed with their broader aspirations and multiple livelihoods. I did not include a comparative group of conventional farmers. The study therefore is not intended to be representative of organic farmers beyond these groups; rather I use thematic analysis to bring out commonalities and 
diversity within farmer experiences. The case study communities were chosen in order to cover three main criteria: a wide geographical area with diverse farming conditions and infrastructure; a variety of development organizations supporting the initiatives; and a variety of quality-control approaches (including export and domestic certified and noncertified systems) and trading approaches (includeing export, urban, local trade, and subsistence). The interviews were conducted in Khmer, either by me or with the aid of my research assistant (a university student in agricultural economics). Local staff of the organic initiatives helped with contacting potential research participants but were not present during interviews. My position as a white foreign woman conducting research with members of development projects presented ethical challenges, including the potential for people to see me as aligned with the organization and to answer questions strategically in the hope of gaining access to agency resources, as well as my need to maintain good relations with the organizations while also exploring the views of farmers beyond the "model" farmers that the organizations usually took me to meet. I attempted to overcome these constraints by emphasizing (both to farmers and organizations) that I was an independent researcher and the results would be kept confidential. Where possible, all members of a village organic group were interviewed, either one-on-one or as part of a focus group. In order to understand how social stratification related to people's experiences of organic agriculture, I attempted to include an equal number of female and male farmers and farmers of various wealth levels.

This research was undertaken in 2007, with follow-up interviews with development agency staff in 2012. The gap of several years since the initial research allows me to incorporate sectoral changes since the study; also, the year 2007 is particularly instructive for a discussion of organics in Cambodia as this period was concurrently one of a shift away from agriculture-based livelihoods and a rapid growth in organic agriculture development programs. I identified more than $30 \mathrm{NGOs}$ and development agencies promoting some kind of organic agriculture or sustainable agriculture program in 2007 (including both domestic and export certified systems, and noncertified systems). The establishment of the Cambodia Organic Agriculture Association (COrAA) in 2006 lent legitimacy to the sector within some areas of the government.

\section{Organic Agriculture Development Programs in Cambodia: Three Case Studies}

Cambodian rice production is seen by development institutions and some parts of the government as a prime prospect for organic agriculture, and the organics sector is heavily donor-driven (COrAA, 2011). Donors point to the combination of fertile land and the plentiful water supply from the Tonle Sap, and the fact that although synthetic chemicals are becoming more widespread in rice production, many farmers still farm without using chemicals (Feuer, 2007). Donors see organics as potentially reducing poverty in a challenging context where farmers generally achieve much lower yields than neighboring countries (in part due to underinvestment in agriculture and lack of irrigation and infrastructural development, high electricity costs, and limited access to and control over land) and often face high debt and vulnerability to weather and market events. Rice production is a priority sector for Cambodia; production increased at 7.4 percent annually from 2000 to 2010 (Food and Agriculture Organization of the United Nations [FAO], 2013). The Cambodian government has a contradictory stance toward organic production: On one hand, the government supports the development of organic smallholder production for self-consumption and export to become the "green farm" of Asia, and is part of the new ASEAN regional organic guidelines currently under discussion $^{1}$; but since the food crisis in 2008, attention has shifted to boosting conventional exports and gaining revenue through large scale land concessions (COrAA, 2011). The COrAA (2011) estimates that the organic sector is small but growing, with around 8,500 farmers cultivating rice organically as part of organic producer groups, and

\footnotetext{
1 The Association of Southeast Asian Nations (ASEAN) Standard for Organic Agriculture (ASOA) is due to be finalized in 2014. It is designed to cover all agricultural croperatives. See http://unfss.files.wordpress.com/2013/ 04/organic unfss.pdf
} 
more than 110,000 farmers implementing some organic techniques. Before discussing the specific benefits and limitations of organic agriculture in this context, I first outline each of the three case studies. I do not suggest that any one of these cases constitutes a model success story; rather I present all three cases in order to show the heterogeneity within organic agriculture projects and the central role of the development organization in structuring the potential for the projects to either reduce or entrench poverty.

\section{German Federal Development Agency (GTZ) Rural Development Program}

The German federal development agency (GTZ, now GIZ) was the major player developing the export organic rice market at the time of research through its Rural Development Program (RDP), with projects involving 700 farmers in two provinces (Kampong Thom and Kampot). The GTZ initiative aimed to create an organic supply chain for organic rice farmers producing for the export market. The first farmers in Kampong Thom became export-certified in 2006. However, GTZ did not manage to establish regular exports during the project time frame (five years) and the project was eventually discontinued. The inability to export was seen by one project staff member I interviewed to be due primarily to corruption within the rice supply chain in Cambodia, a lack of private-sector actors willing to be involved, poor infrastructure, and farmers not honoring contracts. During the project time frame, most of the organic rice produced was marketed through local channels and through a brand ("Saravan") that was sold at markets in Siem Reap and Phnom Penh and gained farmers a 10-percent premium price above local prices for conventional rice.

The GTZ strategy was to create a privatesector value chain for organic rice, which would connect farmers to high-value niche markets in the Global North. This strategy was framed as poverty reduction through trade, with "a more diversified and market-oriented form of agricultural smallscale production together with the development of the agro-industry as the best way out of poverty for Cambodia" (Schmerler, 2006, p. 1). GTZ aimed to develop a functioning private sector and build the capacity of local government and local NGOs, focusing on building horizontal networks (organizing farmers in groups) and vertical networks (linking farmers to wholesalers, retailers, and consumers) (Schmerler, 2006).

\section{Community Cooperative for Rural Development (CCRD) \\ CCRD is a Cambodian NGO involved in} postconflict reconstruction in Pursat province, which moved into organic rice (with funding from Oxfam Quebec) to increase farmer incomes through the sale of certified organic rice to North America and Europe. The NGO originally promoted organic rice as a way to increase incomes through price premiums to the farmers they were already working with, who were mainly conventional farmers. CCRD provided rice seed on credit, and farmers were promised premiums of 5 percent for the first year of organic conversion, and up to 20 percent for fully converted organic systems. However, at the time of my research, CCRD had ceased promoting organic rice cultivation to most of these farmers, as the farmers had experienced difficulties converting their farming systems to fully organic (in line with European Union and U.S. requirements).

The CCRD director told me that "after trying to convert farmers who used chemicals and finding it too hard to convert most, we decided to focus on families who were not using chemicals farmers near the mountains where chemicals had not reached, because they are already organic." CCRD found new farmers who were farming traditional systems (i.e., they were not using synthetic chemicals) in remote districts of the province, and at the time of the research approximately 200 farmers were involved. These farmers were ostensibly provided with minimal training in composting, although more than half the farmers I spoke with told me they had not received any training. The NGO director considered "traditional" systems to be synonymous with "organic" rice systems despite the fact that many farmers who had resettled in the area postconflict told me that much knowledge of soil-enhancement techniques had been lost in the more than 20 years of conflict, or that they did not have time, energy or livestock resources to produce 
and gather manure or use other means to enhance fertility. The farmers I spoke with who were no longer involved with the project were bitter, and one farmer told me that she had adapted her farming system with the expectation of receiving a 20 percent premium for her farm's rice, but now the organization had pulled out and the fragrant variety she had planted in half her fields was not one her family or others at the local market were interested in eating.

Cambodian Center for Study and Development in Agriculture (CEDAC)

The Cambodian NGO CEDAC, funded by the German Development Service (DED), Oxfam Great Britain, and others, runs the largest organic agriculture project in Cambodia. The head of CEDAC, Dr. Koma, reports that the organization began in 1997 and now works with over 3,600 families in 434 organic-rice producers groups. Farmers interested in organic production receive ongoing training through extension agents and peer trainers (i.e., farmers further along the organic conversion process who are paid for their time), including organic techniques (such as use of leguminous cover crops, integrated vegetable gardens, compost and Effective Micro-Organism production), System of Rice Intensification (SRI), savings groups, and livestock and vegetable production. CEDAC developed its own certification using Internal Control System (ICS) inspection and instituted a diverse set of marketing activities for the surplus rice and other produce households produced, including forming producer cooperatives to exchange vegetables from home gardens, assisting farmers in opening stalls selling organic produce at local wet markets, ${ }^{3}$ and developing a brand, "Natural Agri-Products" (NAP), which is sold through CEDAC-owned shops in Phnom Penh and Siem Reap. CEDAC has a fairly decentralized strategy that involves field officers

\footnotetext{
2 System of Rice Intensification (SRI) is a collection of techniques for enhancing rice productivity, under conditions of little or no chemical fertilizers. See http://sri.ciifad.cornell.edu/ ${ }^{3}$ Wet markets are a collection of stalls selling fresh meat and produce (differentiated from dry markets which sell durable goods like cloth and electronics).
}

stationed in different regions and organizing techniques and marketing activities with specific farmer members (although the overall organizational vision is communicated in a top-down approach, which is well critiqued by Feuer (2009)). This strategy means that growing techniques and marketing activities can be tailored for specific areas depending on farmer needs and ecological conditions. For example, in one village in Prey Veng Province, the CEDAC organic group composed of 10 women had successfully organized a stall at the local wet market, where they took turns transporting their produce (by bicycle) and selling on behalf of the group and were able to attract regular price premiums for produce at the local level. Since 2009, CEDAC has begun exporting rice from a producer group in Takeo (made up of approximately 250 households) to the U.S. through Lotus Foods.

\section{Broadening the Debate over the Viability of Organics} In this section, I discuss the case studies presented in relation to the debate over whether organics and other agroecological approaches may benefit smallholder farmers, or may instead entrench poverty by limiting other options for off-farm livelihoods or high-input agriculture. I suggest that several implicit assumptions underlie much of the research informing this debate, including the prioritization of short-term economics (particularly farm-gate prices) in the analysis, and the tendency to assume farmers are a homogenous category of rational economic actors who may freely move to nonagricultural pursuits or into high-input agriculture. I structure the discussion by drawing out four themes from my case studies that show how the debate can be broadened through greater attention to people's diverse (and often non-economic) reasons for pursuing various livelihood options, and to the wider economic, social, and political contexts that structure people's choices.

\section{Going beyond "homo economicus" to understand why people choose to farm organically.}

A focus on enlarging urban and off-farm opportunities for rural people assumes that people want to leave rural areas and that — like the "homo 
economicus" rational, self-interested actor who can freely choose between livelihood options - there are plentiful opportunities into which people move. This assumption is challenged by the growing movements of people around the world who are mobilizing against the conventional food system and defending their rights to a peasant life (McMichael, 2008; 2010); the increasing number of protests in Cambodia over land grabs in recent years are testament to this (Schneider, A. E., 2010). Certainly, some rural people - particularly young people - dream of city life and leaving the physical, isolated work of farming, and I do not suggest a romantic vision that all rural people have a primordial attachment to the land. However, research from Cambodia shows that in many cases, people leave land-based livelihoods because they feel there is no other choice, rather than from a desire to leave (FitzGerald \& Sovannarith, 2007; Schneider, H., 2011). The organic farmers in my study expressed a desire to maintain their farm and a fear that indebtedness and sickness would cause them to sell their land. ${ }^{4}$ I asked research participants how they balanced farm and off-farm livelihoods and why they continued to farm rather than leaving the area as some of their neighbors did. Despite talking about the hard life of a farmer, many farmers said they did not want to go to the city and wage labor would only be spent on buying rice for the family; for example, one farmer from Takeo expressed a sentiment I heard many times during my research: "If we did not [farm] we'd all have to work as laborers and we would spend the income on food anyway" (Takeo, male). Many farmers said that the land and rice itself had value that was beyond a food source or economic commodity. In one village in Takeo with proximity to Phnom Penh's labor market, where the majority of households said at least one family member lived away from the area for work opportunities, many people articulated that if they could just

\footnotetext{
${ }^{4}$ This is not to suggest that this research is representative of all rural people in Cambodia; this is a self-selecting group of farming households whose desire to maintain the viability of their farm is strong enough to engage in the organic project. However, this research involved seven communities from various parts of the country, showing that the desire to maintain a land-based livelihood is significant.
}

make ends meet, they would choose to keep their family together in the village. When I asked farmers what was most important in their idea of a "good life," the majority of people (regardless of gender, wealth, or land ownership (whether renting or owning their plot)) spoke of their desire for selfsufficiency in terms of growing enough rice to feed their family. ${ }^{5}$ Growing "enough rice" meant more than just providing food; people talked about the ability to obtain health care, give their children an education and a big wedding ceremony, maintain livestock, enable them to remain in the countryside, save as a kind of insurance policy in times of need, and provide offerings for the $W$ at (temple). There were interesting contradictions between people's desire to stay on the land and the desire for their children to be educated and gain a position in the city. Migration remittances from family members working in the city or in Thailand or Vietnam were a key aspect of many of the farmer's livelihoods and these were sometimes seen as allowing families to stay on their land. While some interviewees (particularly the teenage daughters of farmers in areas close to Phnom Penh) spoke of their desire to move to the city, others were concerned that city life was a trap, for "people think there are jobs in construction or factories, but they don't find any and end up living on the street or coming back here with nothing because they sold their land" (Pursat, female). Stories abounded in several villages about relatives or neighbors who had gone to the city and failed to find work or been sent back with debts to pay, yet the redecorated houses, motorbikes, and other status symbols of some families that received remittances were testament to the economic benefits of migration for some. These contradictions reflect in part the limited offfarm job opportunities in many urban areas of Southeast Asia (Li, 2011), and growing under-

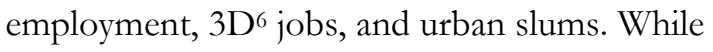
unemployment is still relatively low in Cambodia (NIS, 2010b), this is changing as the population age

\footnotetext{
${ }^{5}$ Other common sentiments were a desire for good health, control over their future, overcoming vulnerability, access to land, control over how and what they grew, and freedom from dependence on others.

${ }^{6}$ Dirty, dangerous, and demeaning (Connell, 1993).
} 
structure $^{7}$ and urban migration mean that 300,000 young people each year are entering the labor force (NIS, 2010b). Access to urban employment is also structured by people's location; in Pursat Province I found that farmers in a roadside village had a much higher level of migration than farmers in villages further away from the paved road. A frequent lament among many farmers in my study was the lack of income-earning opportunities in the village that might allow them to pursue own-farm and local off-farm livelihoods. Agrarian concerns were at the heart of many farmers' conceptions of the "good life" in my research and were not expressed by participants as contradictions to their desires for their children to have an education and a job in the city. Farmers expressed a desire to have choices in planning their livelihoods rather than feeling they have no choice but to leave the land.

\section{Going beyond farm-gate price to assess broader economic and non-economic impacts.} Analyzing farm-gate price alone in a context of uncertain organic price premiums can lead to a conclusion that there is a negligible income benefit from organics. In my study, however, many farmers reported increased household incomes through either lessening dependence on external purchased inputs and/or increasing productivity in rice fields. Farmers with certification or a regular organization-sourced market outlet did receive price premiums of 10 percent (for CEDAC rice and vegetables) and up to 20 percent (for fully certified rice in GTZ and CCRD initiatives). For some farmers this price premium meant increased income of US $\$ 50-U S \$ 150$ for the season (although note that these premiums were not realized longterm, as the following section explains). Most noncertified farmers did not receive price premiums for their produce, although in two CEDAC farmer groups, farmers were able to negotiate slightly higher prices (10 percent over market price) at a group stall at the local wet market (not incidentally, this was in a town where the local

\footnotetext{
${ }^{7}$ Cambodia experienced a post-conflict baby boom in the 1980s that has produced a rapid population increase (from 8 million in 1998 to 14 million in 2008 (NIS, 2010b), and an age structure weighed heavily toward young people.
}

CEDAC extension officer enjoyed a close relationship with local political leaders who supported the group), and through meeting a local trader as a group at one of the farmer's houses.

One farmer newly converting to organic in a noncertified CEDAC project in Takeo reported that her yield had decreased slightly and the prices received for her rice had not changed, so her income was down from the previous year, but she noted, "when we include chemical expenses, we used to spend 300,000 riel, and now we use our own compost and buy some dung for a cost of $100,000 \mathrm{r}$. So we are making 50,000r [US\$12.50] more now and I think our yields will increase." This farmer was one of only three farmers in my study who said that yields had decreased (the other two were members of the CCRD initiative); most farmers (45 of 57 farmers) observed the productivity of their farms had increased since organic conversion. This is significant given that debate over yield in organic agriculture rages on, with recent review studies assessing the global potential for organics to "feed the world" coming to contradictory conclusions (Badgeley et al., 2007; Seufert, Ramankutty \& Foley, 2012). This study was not a systematic comparison with conventional farmer plots, and favorable weather conditions in many areas in the season preceding the study meant rice yields generally improved nationally; however, farmers with both conventional and organic fields also reported that their organic fields were producing higher yields than their conventional fields. ${ }^{8}$ Large yield increases were experienced by CEDAC farmers converting from traditional systems where no soil improvement techniques were previously used, to organic systems utilizing organic compost and SRI production

\footnotetext{
8 This should not be taken as a general causative finding, as this is not a statistical study and was based on a relatively small group of farmers through recall of yields. Several points should be kept in mind when discussing yield increases: where other alternative production methods, such as SRI, were introduced in conjunction with organic systems, yields may be higher; a number of farmers have increased and diversified their production (for example, growing vegetables where before they grew only rice); and weather was favorable in some areas over the 2005-06 growing season, and therefore yields may be higher because of environmental factors.
} 
techniques. Some farmers converting from conventional systems (where chemical inputs were previously used) also reported experiencing yield increases. The most common reasons farmers gave for higher yields included (from those most often mentioned): the use of compost, more care taken in weeding, the use of SRI methods, raising the banks around the rice field to retain organic fertilizer, ploughing in crop remains, digging ponds, access to seed, and investing in other resources such as cattle. The CCRD project was the only site where yields did not generally improve, and this appeared to be due to the minimal changes in farming systems; as noted above, most farmers were not using soil-enhancement techniques (as many said they had received no training), and many of the poorest households did not own sufficient livestock to produce manure, or lacked land or labor due to increased migration for wage work.

Beyond economic aspects, decades of research on the multiple dimensions of poverty and wellbeing indicate that non-economic facets of poverty are central, although these are often downplayed in research due to the difficulty in quantifying them and the tendency to see economics as overly determining (Sen, 1999). In this study, when I asked people about the greatest benefit to them of farming organically, the majority of farmers converting from conventional farming systems cited an improvement in health. Many farmers said they experienced fewer incidences of dizziness, stomach problems, diarrhea, vomiting, and headaches. Considering that many farmers in Cambodia are reported to experience chemical poisoning due to improper use of agrochemicals (Environmental Justice Foundation [EJF], 2002), this result perhaps is not surprising. Some believed this was due to relief from chemical poisoning, while others felt the health improvements were due to a more nutritious, protein-rich diet. Some farmers reported fewer hospital visits, which they said enabled them to save money, while others reported more hospital visits as they now had the income to seek cures for chronic illness. All farmers in the CEDAC and GTZ initiatives, and several in the CCRD initiative, said they were more food-secure since joining the organics initiatives. ${ }^{9}$ Farmers in the CEDAC projects (where integrated home vegetable gardening and fish production in organic rice fields was promoted alongside organic rice techniques) reported greater nutritional diversity due to the ability to grow more vegetables for eating and from selling premium-priced and/or larger amounts of farm produce, which allowed families to buy more protein-rich food. Although these farmers did not include non-rice production in their yield estimates, the multiple crops grown in and around rice fields were important sources of diversified diets and incomes.

An additional non-economic benefit pointed out by many farmers was greater community collaboration with other farmers in the organic project. Farmers said relations with neighbors in the organics group had improved as they attended trainings and meetings together, and shared farmer innovations for new organic techniques and ideas for diversifying into vegetable production, mushroom cultivation, and off-season cropping. Farmers also reported joining the organics groups for political and social status in their communities, including connections with urban and international organizations, access to material resources such as discounted seeds, and free meals at training sessions.

\section{Going beyond the homogenous farmer to understand who benefits and who loses.}

The diversity of interests, resources, and power in local communities is often underemphasized in research that examines farmers as a homogenous group (Scoones, 2009). In this study, while farmers in a range of initiatives could potentially benefit through increased prices, yields, and non-economic benefits, labor constraints and access to resources had a large influence over who joined organic projects and who benefitted. Just over half (31 of 57) the farmers I interviewed perceived labor to increase under organic systems, with labor-heavy

\footnotetext{
${ }^{9}$ Twenty-three (of 57) farmers interviewed said they did not have enough rice previously and could now fully support their families with enough rice for the entire year. Others had improved by a smaller degree; a minority had always been able to support their family.
} 
tasks cited as nursery preparation, weeding, and compost preparation (agreeing with Scialabba \& Hattam, 2002; International Fund for Agricultural Development [IFAD], 2003). All three NGOsponsored projects tended to exclude the poorest, most marginalized people in the community, as well as the wealthiest; the majority of farmers in all projects described themselves as "poor" or "middle income" rather than "poorest." At a basic level, in order to join the initiatives farmers required access to land and a certain security of tenure, and sufficient labor (or ability to hire labor), which meant that households with little or no agricultural land, and no available labor, could not benefit. I did not find that farmers in areas more accessible to Phnom Penh or other urban labor markets were less likely to join the organics initiatives due to labor shortages, but this was perhaps due to donor or NGO decisions to site projects in areas with less urban migration. As one NGO extension agent told me, he was "not promoting the organic rice programs in this area [close to the National road to Phnom Penh] anymore. People in this village are all going to the city to work, and the old people don't want to take it up." In all study areas, I noted that older farmers whose children had moved away to the city said that labor shortages for some jobs were acute. The projects did not tend to attract upwardly mobile households where multiple adult household members had full-time off-farm income sources, and some non-adopting households I spoke with said they did not have the on-farm labor necessary to be part of the organics initiatives, nor the resources to hire labor. Many farmers, however, noted no change in labor, or a reduction in labor requirements under organic systems. This was particularly the case where SRI techniques were taught as part of the organic training (indeed, for many of the farmers in CEDAC's Takeo project, they equated "SRI" with "organic," as CEDAC encouraged all its organic farmers to use SRI techniques). One focus group had a heated discussion about whether organic farming increased or decreased labor requirements. Some said the SRI method of transplanting young seedlings was easier than traditional methods and argued that this offset the extra labor required for compost and weeding in organic systems. Women- headed households in two CEDAC initiatives said that the organic systems (in which they used SRI planting methods) required less heavy work as young seedlings were lighter to pull and transplant, and that this enabled them to cultivate even though the men in the household were working in Phnom Penh. SRI methods are not synonymous with organic agriculture, but appear to work well in organic and low-input systems in Cambodia (although the benefits of SRI are widely debated in the broader literature ((Uphoff, 2004), and these findings suggest that more research into the abilities for SRI methods to reduce labor requirements in organic systems be pursued (Resurreccion, Sajor, \& Sophea, 2008)).

\section{Understanding the roles of diverse development actors.}

I selected these three case studies in part to disrupt an assumption that organic is equated with a romanticized notion of traditional farming or a certain strategy of export-certified, long-distance trade. The farmers profiled here all considered themselves to be organic farmers, but their marketing and certification strategies differed significantly, and this has implications for whether organics could be considered a benefit or a "poverty trap." A common concern in the literature is the potential for organic certification to come with high costs for farmers, and to be inappropriate for local ecological and social contexts (Friedberg \& Goldstein, 2011; Melo \& Wolf, 2007). In this study, more than half the farmers in the export-certified groups said they felt that certification was a benefit to them, due to perceived increased trust and access to lucrative markets. However, one central issue with certification was financial cost; the annual payment for an external inspector for the GTZ and CCRD projects was estimated by different groups to be between US $\$ 500-$ US $\$ 2,000$ per day for up to three days of inspection (plus their travel costs from Germany). The development agencies were paying this cost at the time of research, but this left the farmers in a vulnerable position as they felt there was no way they could finance the certification costs for the long term. As one GTZ employee said, "in future if nobody steps in to take over 
certification costs then it's over." Many farmers said internal inspections (carried out in CEDAC villages practicing ICS certification) were more effective than external inspections, due to perceived higher levels of trust between internal inspectors and farmers, the ability to monitor the farm year-round, and more flexible certification requirements. The dangers of reliance on external funding were illustrated during the 2008 recession, when CEDAC lost a key loan and was unable to purchase much of the rice it had planned to (COrAA, 2011), and in the case of GTZ and CCRD, farmers were unable to maintain their certified status and networks when project funding ended (COrAA 2011).

One requirement for GTZ and CCRD export certification that was not included in CEDAC certification was the need to convert the entire farm to an organic system. Many farmers were not in compliance with this requirement at the time of research, as they preferred to minimize risk by converting only a part of their system, and offseason crops such as cassava were more difficult to grow organically. Some farmers felt that a second requirement for the construction of "buffer zones" around organic rice fields in order to prevent chemical pollution from other fields was difficult to comply with. In one of the GTZ project villagers, a farmer told me she had pulled out of the project as she was one of the poorest farmers in the village and her rice land was in a flood-prone area, where it was impossible to prevent water contamination from the neighboring conventional fields. A further requirement to grow fragrant varieties in certified systems in all three organizations also limited the ability for some farmers to benefit. Development staff said fragrant varieties (including Phkar Roumdoul and Phkar Malis) were essential for entering niche markets, and some farmers felt that the availability of these quality seeds was one of the biggest benefits of the organics initiatives because they fetched higher prices at distant markets and with some local traders. However, these are medium-duration varieties that are generally grown earlier in the wet season; as they are not as tall as long-duration varieties, they are vulnerable to flooding in lowelevation fields (Vang, 2011), and this limited the ability of farmers with unsuitable land to join the projects. Indeed, two farmers said they could not produce organic rice to sell to the association in the current season because the seed variety was not suited to their land. Several farmers said that these varieties were not what they or others in their local area were accustomed to eating, and that they were not suitable for using in some staple dishes. Most farmers therefore grew the fragrant varieties as cash crops but continued to grow traditional varieties for household consumption and local markets.

The case studies show that the ideology and objectives of the development agency have a large bearing on farmer experiences. The tendency to "depoliticization" that often describes development projects ( $\mathrm{Li}, 2007)$ was observed in all three projects, as the development organizations' tendency to focus on reporting and donor-driven accountability limited the ability of development agents to work with marginalized groups and to acknowledge broader non-economic values. However, the CEDAC project is notable in this regard because of the initial ideology guiding the project's design, which was rooted in notions of farmer independence, health, and food security through household production, and allowed for a broader definition of success than simply fulfilling export shipments. Whereas other projects focused from the beginning on developing organics as a niche market for the Global North, CEDAC's approach to first building household food security and local markets meant that farmers had access to more diverse marketing strategies and were less vulnerable to dependence on volatile long-chain markets.

\section{Suggestions for Further Research}

This study could only give a snapshot of farmers' experiences, and while I attempted to move away from an economistic view of organic agriculture's benefits and costs, lack of time meant I was not able to pursue long-term ethnographic research through several growing seasons. To help us understand how households manage multiple livelihood sources, I suggest that further research focus on long-term studies on various organic farming approaches in Cambodia and their 
relationships with nonfarm livelihoods and broader structural changes in rural areas. The ambiguous results for labor requirements under organic systems should be further examined, particularly the reasons why farmers experience increases or decreases in labor requirements and the gender dimensions of labor burden. Research on technologies that may reduce labor burden (including SRI and cooperatively owned tractors and other implements) should be pursued to understand their impacts on farmers with different resource levels. My research was limited to social impacts, and more work is needed on the ecological potential for organics to reduce long-term vulnerability to weather events and economic crises in various regions of the country. Finally, comparative research with farmers in areas with high labor mobility (e.g., roadside and border villages) and more remote areas will clarify the relationship between uneven agrarian transitions and farmer experiences of organics.

\section{Conclusion: Pursuing Organic Agriculture Within a Re-Envisioning of Rural Spaces in the Global South}

Overall, my analysis shows that participation in organic farming projects is a successful strategy for some households, but it is not a panacea for rural poverty in Cambodia. Direct economic benefits are uncertain; non-economic benefits, broader contexts of uneven agrarian transition, and development agency approaches have a large bearing on the poverty-reduction potential of organics. No development project initiated and managed by people external to a community — and funded by agencies even further spatially and ideologically removed — is likely to be completely empowering or sustainable for farmers. Indeed, as the three case studies presented here show, organic agriculture development projects have the potential to increase dependence on external development agents and exposure to volatile international markets. However, these case studies also illustrate the potential for organic agriculture development projects to have positive outcomes for farmers. The CEDAC projects in particular can be seen as most closely aligned with an agro-ecological understanding that values diversity and farmer knowledge, and farmers in those projects were able to increase their food security and incomes through a variety of techniques and market channels, as well as diversify their farming systems.

Do any of these benefits really matter, though, if they only earn farmers US $\$ 50$-US $\$ 100$ extra per season, while sending a family member to Phnom Penh to work in garment factories could net US $\$ 50-U S \$ 100$ per month? The evidence presented here shows that while organic farming is a successful strategy for some households to improve the viability of land-based livelihoods, it is not a panacea for rural poverty in Cambodia by itself. I found it to be inaccessible to households with inadequate labor and land, and some farmers said labor costs increased and certification compliance was difficult. The limitations of the development project as a delivery mechanism and the underlying structural inequalities that remain unchallenged also limit organic agriculture's transformative potential. However, interviewees expressed uncertainty about other livelihood options in some areas, and many of them desired to continue farming while pursuing multiple livelihood strategies. In addition, the noneconomic benefits reported (such as better health, debt reduction, and stronger community ties) suggests that any answer to whether organic agriculture reduces or entrenches poverty is complex.

If organic agriculture is pursued as part of a comprehensive rural-development strategy that focuses on diverse elements such as land redistribution, extension, health and education services, and rural employment opportunities, organics can be a vital part of a set of livelihood choices for rural people. Considering the likelihood of continuing fluctuations and price increases in fuel costs and chemical inputs, as well as in transportation, the notion of promoting "modernized" agriculture as the way to address farmer poverty and food security is troubling from a long-term perspective. Finally, considering that rural people may not want to leave a farming livelihood, and that rice has value beyond as a foodstuff that can be purchased, I suggest that the terms of the question I posed in this paper need to be altered. We need to move beyond asking whether organics is viable 
in a context of rapid transition out of agriculture. Instead, we need to ask how we can support rural communities to be viable, vibrant places, with ecologically sustainable food production at the center of diverse local economies that provide a variety of land-based and off-farm livelihood opportunities for people. Within this vision, organic agriculture can play a significant role.

\section{Acknowledgements}

This research was supported by a Sasakawa Young Leaders Fellowship from the Tokyo Foundation.

\section{References}

Akram-Lodhi, A. H., \& Kay, C. (2010a). Surveying the agrarian question (part 1): Unearthing foundations, exploring diversity. Journal of Peasant Studies, 37(1), 177-202. http://dx.doi.org/10.1080/03066150903498838

Akram-Lodhi, A. H., \& Kay, C. (2010b). Surveying the agrarian question (part 2): Current debates and beyond. Journal of Peasant Studies, 37(2), 255-284. http://dx.doi.org/10.1080/03066151003594906

Allen, P., \& Kovach, M. (2000). The capitalist composition of organic: The potential of markets in fulfilling the promise of organic agriculture. Agriculture and Human Values, 17(3), 221-232. http://dx.doi.org/10.1023/A:1007640506965

Araya, H., \& Edwards, S. (2004). The Tigray experience: A success story in sustainable agriculture (Environment and Development Series No. 4). Penang, Malaysia: Third World Network. Retrieved from http://www.twnside.org.sg/title/end/pdf/ end04.pdf

Bacon, C. (2005). Confronting the coffee crisis: Can fair trade, organic, and specialty coffees reduce smallscale farmer vulnerability in northern Nicaragua? World Development, 33(3), 497-511. http://dx.doi.org/10.1016/j.worlddev.2004.10.002

Badgley, C., Moghtader, J., Quintero, E., Zakem, E., Chappell, M. J., Avilés-Vázquez, K.,...Perfecto I. (2007). Organic agriculture and the global food supply. Renewable Agriculture and Food Systems, 22(2), 86-108. http://dx.doi.org/10.1017/S1742170507001640

Barham, B. L., \& Callenes, M. (2011). Fair Trade/organic coffee, rural livelihoods, and the "agrarian question": Southern Mexican coffee families in transition. World Development, 39(1), 134-145. http://dx.doi.org/10.1016/j.worlddev.2010.08.005

Bernstein, H. (1996). Agrarian questions then and now. Journal of Peasant Studies, 24(1-2), 22-59. http://dx.doi.org/10.1080/03066159608438630

Beuchelt, T. D., \& Zeller, M. (2011). Profits and poverty: Certification's troubled link for Nicaragua's organic and fairtrade coffee producers. Ecological Economics, 70(7), 1316-1324. http://dx.doi.org/10.1016/i.ecolecon.2011.01.005

Byres, T. J. (1986). The agrarian question, forms of capitalist agrarian transition and the state: An essay with reference to Asia. Social Scientist, 14(11/12), 3-67. http://dx.doi.org/10.2307/3517162

Cambodia Organic Agriculture Association [CorAA]. (2011). Organic agriculture and food processing in Cambodia: Status and potentials. Phnom Penh: Author. Retrieved from http://www.coraa.org/

Cambodian League for the Promotion and Defense of Human Rights [LICADHO]. (n.d). The great Cambodian giveaway: Visualizing land concessions over time. Retrieved September 8, 2013, from http://www. licadho-cambodia.org/concession timelapse/

Chandler, D. (2008). A history of Cambodia. Boulder, Colorado: Westview Press.

Connell, J. (1993). Kitanai, kitsui and kiken: The rise of labor migration to Japan. Sydney: Economic and Regional Restructuring Unit, University of Sydney.

Environmental Justice Foundation [EJF]. (2002). Death in small doses: Cambodia's pesticides problems and solutions. London: Author. Retrieved from http://ejfoundation.org/pesticides/death in small doses

Feuer, H. (2007). Sustainable agricultural techniques and performance oriented empowerment: An actor network theory approach to CED $A C$ agricultural and empowerment programmes in Cambodia (unpublished report). Oxford: Oxford Department of International Development, University of Oxford.

FitzGerald, I., \& Sovannarith, S. (2007). Moving out of poverty? Trends in community well-being and housebold mobility in nine Cambodian villages. Phnom Penh: Cambodia Development Resource Institute [CDRI].

Food and Agriculture Organization of the United Nations [FAO]. (2013). FAO Statistical Yearbook 2013: World Food and Agriculture. Rome: Author. Retrieved from http://www.fao.org/docrep/018/ i3107e/i3107e00.htm 
Food and Agriculture Organization of the United Nations Statistics [FAOSTAT]. (2013). Cambodia population and production statistics. Retrieved from http://faostat.fao.org

Ruben, R., \& Fort, R. (2012). The impact of Fair Trade certification for coffee farmers in Peru. World Development, 40(3), 570-582. http://dx.doi.org/10.1016/j.worlddev.2011.07.030

Friedberg, S., \& Goldstein, L. (2011). Alternative food in the global south: Reflections on a direct marketing initiative in Kenya. Journal of Rural Studies, $27(1), 24-34$. http://dx.doi.org/10.1016/j.jrurstud.2010.07.003

Guthman, J. (2004). Agrarian dreams: The paradox of organic farming in Califormia. Berkeley: University of California Press.

Hall, D., Hirsch, P., \& Li, T. M. (2011). Powers of exclusion: Land dilemmas in Southeast Asia. Honolulu: University of Hawaii Press.

Hart, G., Turton, A., \& White, B. (Eds.). (1989). Agrarian transformations: Local processes and the state in Ssoutheast Asia. Berkeley and Los Angeles: University of California Press.

Heder, S. (1995). Cambodia's democratic transition to neoauthoritarianism. Current History., 94(596), 425-429.

International Assessment of Agricultural Knowledge, Science and Technology for Development [IAASTD]. (2008). Agriculture at a crossroads synthesis report. Washington, D.C.: Author. Retrieved from http://www.unep.org/dewa/assessments/ ecosystems/iaastd/tabid/105853/default.aspx

International Fund for Agricultural Development [IFAD]. (2003). The adoption of organic agriculture among small farmers in Latin America and the Caribbean: Thematic evaluation. Rome: Author. Retrieved from http://www.ifad.org/

Kautsky, K. (1899/1988). The agrarian question. London: Zwan.

Kimsun, T. (2011). Migration, remittances and poverty reduction: Evidence from Cambodia. Cambodia Development Review, 15(4), 7-12. http://www.cdri.org.kh/

Lenin, V. I. (1956). The development of capitalism in Russia: The process of the formation of a home market for large-scale industry. Moscow: Foreign Languages Publishing House.
Li, T. M. (2007). The will to improve: Governmentality, development and the practice of politics. Durham: Duke University Press.

Li, T. M. (2009). Exit from agriculture: A step forward or a step backward for the rural poor? Journal of Peasant Studies, 36(3), 629-636. http://dx.doi.org/10.1080/03066150903142998

Li, T. M. (2011). Centering labor in the land grab debate. Journal of Peasant Studies, 38(2), 281-298. http://dx.doi.org/10.1080/03066150.2011.559009

Löhr, D. (2011).The Cambodian land market: Development, aberrations, and perspectives. ASIEN, 120, 28-47. http://www.asienkunde.de

Mayers, J., \& Vermeulen, S. (2005). Stakeholder influence mapping. London: International Institute for Environment and Development.

McMichael, P. (2008). Peasants make their own history, but not just as they please... Journal of Agrarian Change, 8(2-3), 205-228. http://dx.doi.org/ 10.1111/j.1471-0366.2008.00168.x

McMichael, P. (Ed.). (2010). Contesting development: Critical struggles for social change. London and New York: Routledge.

Melo, C. J., \& Wolf, S. A. (2007). Ecocertification of Ecuadorian bananas: Prospects for progressive North-South linkages. Studies in Comparative International Development, 42(3-4), 256-278. http://dx.doi.org/10.1007/s12116-007-9009-1

National Institute of Statistics [NIS]. (1997). Cambodia socio-economic survey 1997. Retrieved from http://nada.nis.gov.kh/index.php/catalog/7

NIS. (2010a). Cambodia socio-economic survey, 2009. Retrieved from http://www.nis.gov.kh/index.php/en/

NIS. (2010b). Labour force 2007. Retrieved from http://www.nis.gov.kh/nis/CSES/NIS_CSES_ Report Labour\%20Force Final290110.pdf

Paarlberg, R. (2010, April 26). Attention Whole Foods shoppers. Foreign Policy. Retreived from http://www.foreignpolicy.com/

Parrott, N., Olesen, J. E., \& Høgh-Jensen, H. (2006). Certified and non-certified organic farming in the developing world. In N. Halberg, H. Alroe, M. Knudsen \& E. Kristensen (Eds.), Global development of organic agriculture: Challenges and promises (pp. 153180). Wallingford, UK: CAB International. http://dx.doi.org/10.1079/9781845930783.0153 
Pretty, J. N., Noble, A. D., Bossio, D., Dixon, J., Hine, R. E., Penning de Vries., Morison, J. I. L. (2006). Resource-conserving agriculture increases yields in developing countries. Environmental Science and Technology, 40(4), 1114-1119. http://dx.doi.org/10.1021/es051670d

Resurreccion, B. P., Sajor, E. E., \& Sophea, H. (2008). Gender dimensions of the adoption of the System of Rice Intensification (SRI) in Cambodia. Phnom Penh: Oxfam.

Rigg, J. (2006). Land, farming, livelihoods, and poverty: Rethinking the links in the Rural South. World Development, 34(1), 180-202. http://dx.doi.org/10.1016/j.worlddev.2005.07.015

Rigg, J. (2012). Joining the dots of agrarian change in Asia: A 25 year view from Thailand. World Development, 40(7), 1469-1481. http://dx.doi.org/10.1016/j.worlddev.2012.03.001

Schmerler, C. (2006). V alue chain promotion: Experiences with organic rice from Cambodia. Phnom Penh: GTZ Rural Development Program.

Schneider, A. E. (2010). What will we do without our land? Land grabs and resistance in rural Cambodia. (Master's thesis). Saint Mary's University, Halifax, Canada.

Schneider, H. (2011). Development at the expense of the environment and the poor: The conflict for Boeng Kak lake in Phnom Penh, Cambodia. Pacific News, 36, 4-10.

Scialabba, N. E.-H., \& Hattam, C. (Eds.). (2002). Organic agriculture, environment and food security. Rome: FAO. Retrieved from http://www.fao.org/docrep/005/ $\mathrm{v} 4137 \mathrm{e} / \mathrm{y} 4137 \mathrm{e} 00 . \mathrm{htm}$

Scoones, I. (2009). Livelihoods perspectives and rural development. Journal of Peasant Studies, 36(1), 171-196. http://dx.doi.org/10.1080/03066150902820503

Sen, A. (1999). Development as freedom. New York: Knopf. Seufert, V., Ramankutty, N., \& Foley, J. A. (2012). Comparing the yields of organic and conventional agriculture. Nature, 485, 229-232.

http://dx.doi.org/10.1038/nature11069

Springer, S. (2009a). Culture of violence or violent Orientalism? Neoliberalisation and imagining the 'savage other' in post-transitional Cambodia.
Transactions of the Institute of British Geographers, 34(3), 305-319. http://dx.doi.org/10.1111/j.14755661.2009.00344.x

Springer, S. (2009b). Renewed authoritarianism in Southeast Asia: Undermining democracy through neoliberal reform. Asia Pacific Viewpoint, 50(3), 271-276. http://dx.doi.org/10.1111/j.1467$\underline{8373.2009 .01400 . x}$

Taotawin, N. (2010). The transition from conventional to organic rice production in northeastern Thailand: Prospect and challenges. In M. Beniston (Ed.), Environmental change and agricultural sustainability in the Mekong Delta (Advances in Global Change Research Vol. 45) (pp. 411-436). Dordrecht, Germany: Springer.

Thavat, M. (2011). The tyranny of taste: The case of organic rice in Cambodia. Asia Pacific Viewpoint, 52(3), 285-298. http://dx.doi.org/10.1111/i.1467$\underline{8373.2011 .01458 . x}$

Üllenberg, A. (2009). Foreign direct investment (FDI) in land in Cambodia. Eschborn, Germany: Deutsche Gesellschaft für Technische Zusammenarbeit [GTZ]. http://www2.gtz.de/wbf/4tDx9kw63gma/ gtz2010-0061en-foreign-direct-investmentcambodia.pdf

Uphoff, N. (2004). System of Rice Intensification responds to 21st century needs. Rice Today, 3(3), 42.

Vandergeest, P. (2011, February 17). New Green Revolutions in Thailand: What we can learn from a global south perspective on alternative agriculture. Cornell University Southeast Asia Program Seminar Series, Ithaca, New York.

Vang, S. (2011, July). Country report on rice cultivation practice: Cambodia. CARDI Expert Meeting, Bangkok, Thailand.

World Bank, Public Information Center [PIC]. (2006). Cambodia: Halving poverty by 2015? Poverty assessment 2006. Phnom Penh: World Bank PIC Cambodia. Retrieved from http://go.worldbank.org/LWTE2DIAI1

World Bank. (2013). World development indicators, agriculture, value added. Retrieved from http://data.worldbank. org/indicator/NV.AGR.TOTL.ZS 